\title{
Human bocavirus respiratory infection in infants in Córdoba, Argentina
}

\author{
Laura Moreno, M.D., ${ }^{a}$ Leticia Eguizábal, M.D., ${ }^{a}$ Lucía María Ghietto, M.D., ${ }^{b}$ Elizabeth Bujedo, Biologist, ${ }^{a}$ and \\ María Pilar Adamo, M.D. ${ }^{b}$
}

\begin{abstract}
It has been suggested that human bocavirus $(\mathrm{HBoV})$ is related to acute respiratory infection (ARI) in children (prevalence: $0.9 \%$ to $33 \%$ ) although clinical characteristics have not been clearly established yet.

Objectives. To identify the presence of $\mathrm{HBoV}$ in patients with ARI hospitalized in Hospital de Niños de Córdoba and describe cases without co-infection.

Method. HBoV screening was done by traditional PCR. Specimens to be screened were obtained from nasal secretions of 222 children under 2 years of age hospitalized due to an ARI during 2011. Demographic, clinical and radiological data were recorded.

Results. Fifteen $\mathrm{HBoV}+$ patients $(6.8 \%)$ were identified. Their median age was 3.5 months (range: 1-22), 7/15 in co-infection (5 respiratory syncytial virus, 1 parainfluenza-3, 1 Bordetella pertussis). Cases without co-infection: pneumonia 5/8, bronchiolitis $3 / 8$; two required intermediate care, $7 / 8$ oxygen therapy, $7 / 8$ bronchodilators, $6 / 8$ antibiotics; associated disease $1 / 8$ (microcephalus/heart disease).

Conclusions. HBoV was identified in 15 out of 222 children (6.8\%); the diagnosis of pneumonia was predominant without severe cases nor complications upon discharge.

Key words: human bocavirus, acute respiratory infection, pneumonia, infants.

http:/ /dx.doi.org/10.5546/aap.2014.eng.70
\end{abstract}

\section{INTRODUCTION}

Acute respiratory infection (ARI) is a significant cause of infant morbidity and mortality. ${ }^{1}$ Bronchiolitis and pneumonia are the main conditions that require hospitalization.

a. Chair of Clinical Pediatrics, School of Medicine, Universidad Nacional de Córdoba. Hospital de Niños Santísima Trinidad, Córdoba.

b. Institute of Virology J. M. Vanella, School of Medicine, Universidad Nacional de Córdoba.

c. Immunology laboratory. Hospital de Niños Santísima Trinidad, Córdoba.

E-mail Address:

Laura B. Moreno, M.D.: lauramoreno@arnet.com.ar

Conflict of Interest: None.

Received: 04-03-2013

Accepted: 07-10-2013
Human bocavirus (HBoV), a parvovirus described by Allander, et al. has been recently added to the long list of microorganisms and viruses involved (2005). ${ }^{2}$

It has been shown that this virus has implications in wheezing ${ }^{3}$ and respiratory infections. ${ }^{4}$

Prevalence in children with respiratory disease is significantly different, ranging from $0.9 \%$ to $33 \%$ in various series ${ }^{5,6}$ Locally, studies in symptomatic children and adults have shown variable frequencies ( $15 \%$ to $22 \%$ ), according to the year they were registered. ${ }^{7,8}$ Besides, studies about seroprevalence revealed an immune response in all ages, indicating a wide distribution in the human population as well as an early incidence of the infection. ${ }^{9}$

Aiming at providing local epidemiological data on the presence of $\mathrm{HBoV}$ in our setting, we decided to estimate its prevalence in children younger than 2 years old hospitalized due to an ARI, and to describe the characteristics of positive cases without proven bacterial nor viral co-infection.

\section{MATERIAL AND METHODS}

Children younger than 2 years old hospitalized in Hospital de Niños de Córdoba because of community-acquired ARI (JanuaryDecember, 2011) and whose parents accepted to participate were included in the study. The case history, clinical examination, chest X-ray, blood count/differential blood count were done and nasopharyngeal aspirate specimens were collected. Immunoflourescence (IF) tests were carried out for syncytial respiratory virus (SRV), parainfluenza (PIV) 1-2-3, influenza (FLU) A and $\mathrm{B}$, adenovirus (AV) and human metapneumovirus (hMPV). A fraction $(200 \mu \mathrm{L})$ of the supernatant was retained for $\mathrm{HBoV}$ search by traditional PCR and sequencing in compliance with a previously described protocol. ${ }^{7,8}$ Bordetella pertussis was investigated when it was appropriate and also 
common microorganisms were investigated in cases of pneumonia. X-rays were interpreted following standardized patterns: condensation or pleural effusion (pattern 1), interstitial infiltrates, interstitial and alveolar infiltrates, atelectasis (pattern 2), and normal X-ray or air trapping (pattern 3). Regardless of the study, patients were managed according to the treating physician's judgement. The protocol was approved by the hospital's Ethics Committee.

\section{RESULTS}

Two hundred and twenty two patients out of the total number (297) of patients who met the inclusion criteria were invited to participate, they signed the informed consent and completed the protocol requirements, including nasopharyngeal aspirate specimen collection (75\%; 95\% CI: 69-79). In 104 (46.8) of them some kind of respiratory virus was identified. Among virus detected by IF, SRV was the most predominant one, with a detection rate of $48 / 222(21.6 \%)$, followed by PI-3 virus with $23 / 222$ (10.4\%), hMPV with $10 / 222(4,5 \%)$, Flu A with 6/222 (2.7\%), and AV with $2 / 222(0.9 \%)$. Fifteen $\mathrm{HBoV}+$ cases were identified by PCR $(6.8 \%$, all of them HBoV1) with an age range from 1 to 22 months (median 3.5; $64.3 \%<6$ months). The sample characteristics are detailed in Table 1.

The population distribution by epidemiological week is presented in Figure 1; HBoV showed an endemic-epidemic behavior.

Seven of the $15(46,7 \%) \mathrm{HBoV}+$ cases had coinfection (SRV 5, PI $1 \mathrm{~V}$ and Bordetella pertussis1). A 22 month old patient with previous associated disease (genetic syndrome/heart disease/ microcephalus) had pneumonia without severe involvement nor complications (discharged at 6 days). Table 2 sums up the characteristics of $\mathrm{HBoV}+$ cases without identified co-infections nor associated diseases (selected to optimize the description of the condition). Most of the

TABLE 1. General characteristics of the studied population. It includes HBoV+cases (with and without co-infection). Hospital de Niños de Córdoba, 2011 (n=222)

\begin{tabular}{|c|c|c|}
\hline & Total $n=222$ & $\mathrm{HBoV}+\mathrm{n}=15$ \\
\hline Age (months)* & $6 \pm 5(1-24)$ & $6 \pm 6(1-22)$ \\
\hline Boys & $108(49 \%)$ & 9 \\
\hline Previous associated disease & $33(15 \%)$ & 1 \\
\hline Preterm newborn infant & $23(10 \%)$ & 2 \\
\hline History of recurrent wheezing & $75(34 \%)$ & 7 \\
\hline Family history of asthma & $22(10 \%)$ & 1 \\
\hline Exclusive maternal breastfeeding (6 months) & $123(55 \%)$ & 9 \\
\hline Smoking in the household & $48(22 \%)$ & 4 \\
\hline Symptomatic cohabitant & $26(12 \%)$ & 3 \\
\hline Attending a day-care center & $6(3 \%)$ & 0 \\
\hline Prodromal days* & $3.5 \pm 2(1-10)$ & $3 \pm 2(1-9)$ \\
\hline Hospitalization days* & $8.5 \pm 5(2-21)$ & $9 \pm 5(2-21)$ \\
\hline Days with oxygentherapy* & $4 \pm 5(0-19)$ & $4 \pm 5(0-19)$ \\
\hline IMCU requirement & $74(33 \%)$ & 5 \\
\hline ICU requirement/complications/death & $3(1 \%)$ & 0 \\
\hline Positive cases for respiratory virus by IF & $104(49 \%)$ & 6 \\
\hline Positive cases for Bordetella pertussis & $13(6 \%)$ & 1 \\
\hline
\end{tabular}

*Average \pm SD (range). **n (\%).

IMCU: Intermediate Care Unit.

ICU: Intensive Care Unit. 


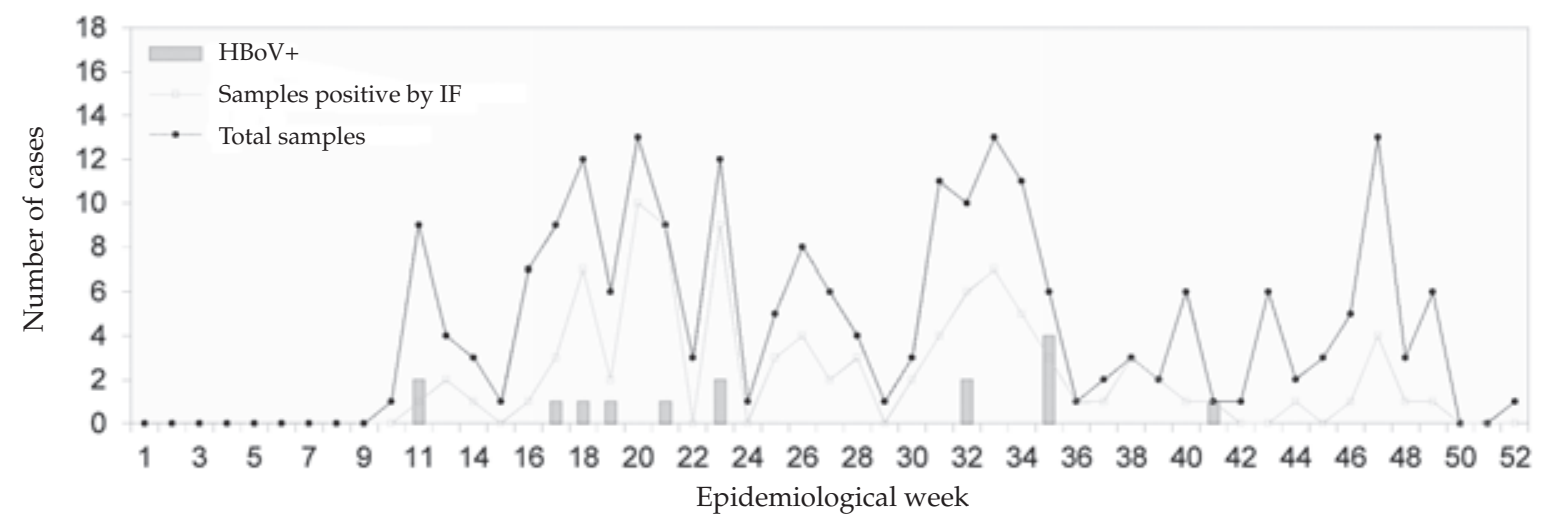

IF: inmunofluorescence (diagnostic panel for respiratory syncytial virus, influenza, parainfluenza, adenovirus and metapneumovirus).

TABLE 2. Characteristics of HBoV+ cases without proven co-infection. Hospital de Niños de Córdoba, 2011

\begin{tabular}{|c|c|c|c|c|c|c|c|}
\hline & Case A & Case B & Case C & Case D & Case E & Case F & Case G \\
\hline Age (months) & 3 & 9 & 14 & 11 & 1 & 2 & 1 \\
\hline Sex & M & $\mathrm{F}$ & M & M & M & $\mathrm{F}$ & $\mathrm{F}$ \\
\hline Month & March & April & May & June & June & August & August \\
\hline Symptomatic cohabitant & No & No & No & No & Yes & No & Yes \\
\hline History & Prematurity & RoB & RoB & RoB & No & No & No \\
\hline Family smoking & Yes & No & No & No & No & Yes & No \\
\hline Prodromal (days) & 1 & 2 & 1 & 1 & 1 & 7 & 5 \\
\hline Hospitalization (days) & 8 & 6 & 5 & 7 & 7 & 2 & 4 \\
\hline White blood cell/mL & 16000 & 14500 & 15800 & 14600 & 10000 & 10140 & 15300 \\
\hline Band cells (\%) & 1 & 0 & 0 & 0 & 0 & 1 & 1 \\
\hline Polynuclear leukocytes (\%) & 22 & 75 & 79 & 71 & 53 & 34 & 32 \\
\hline Absolute neutrophils (per mL) & 3520 & 10850 & 12482 & 10366 & 5300 & 3549 & 4052 \\
\hline $\operatorname{ESR}(\mathrm{mm} / 1 \mathrm{~h})$ & 12 & 23 & 25 & 35 & 39 & 6 & 34 \\
\hline $\begin{array}{l}\text { Chest X-ray (a MS description } \\
\text { and pattern) }\end{array}$ & $\begin{array}{l}\text { Infiltrates } \\
\text { interstitial } \\
\text { (pattern 2) }\end{array}$ & $\begin{array}{l}\text { Infiltrates } \\
\text { interstitio- } \\
\text { alveolar } \\
\text { (pattern 2) }\end{array}$ & $\begin{array}{l}\text { Infiltrates } \\
\text { interstitio- } \\
\text { alveolar } \\
\text { (pattern 2) }\end{array}$ & $\begin{array}{c}\text { Infiltrates } \\
\text { interstitio- } \\
\text { alveolar } \\
\text { (pattern 2) }\end{array}$ & $\begin{array}{c}\text { Infiltrates } \\
\text { interstitio- } \\
\text { alveolar } \\
\text { (pattern 2) }\end{array}$ & $\begin{array}{c}\text { Air trapping } \\
\text { (pattern 3) }\end{array}$ & $\begin{array}{c}\text { Normal } \\
\text { (pattern 3) }\end{array}$ \\
\hline Oxygen therapy (days) & 2 & 3 & 3 & 4 & No & 2 & 4 \\
\hline Mechanical respiratory assistan & nce No & No & No & No & No & No & No \\
\hline Bronchodilators & Yes & Yes & Yes & Yes & No & Yes & Yes \\
\hline IMCU requirement & No & No & Yes & Yes & No & No & No \\
\hline Diagnosis upon discharge & $\begin{array}{l}\text { Apnea/ } \\
\text { bronchiolitis }\end{array}$ & Pneumonia & Pneumonia & Pneumonia & Pneumonia & Bronchiolitis & Bronchiolitis \\
\hline Complications/death & No & No & No & No & No & No & No \\
\hline
\end{tabular}

RoB: Recurrent obstructive bronchitis.

IMCU: Intermediate Care Unit. 
patients had wheezing which required oxygen therapy (6/7) and bronchodilators (6/7). A patient with bronchiolitis developed apnea; the patient had a history of preterm birth (without pulmonary disease). Pneumonia with interstitialalveolar infiltrates (pattern 2 ) in chest X-rays was predominant with little increase of temperature. Hemoglobin levels showed no pathological abnormalities for the age; no gastrointestinal symptoms nor skin manifestations were observed either. Most of the patients (6/7) were treated with antibiotics during hospitalization (ampicillin, clarithromycin, gentamicin). Two required intermediate care during 2 and 8 days, respectively; none required intensive care. From the comparative analysis among $\mathrm{HBoV}+$ cases with and without co-infection, the only difference was observed in the length of stay (12 \pm 6 versus $6 \pm 2 ; p=0.018$ ).

\section{DISCUSSION}

The rate of $\mathrm{HBoV}$ detection was $6.8 \%$, a little lower than that previously detected in Córdoba (15.9\%, 24.6\% and 28.2\% in 2007, 2009 and 2010, respectively). ${ }^{7,8}$ This variability could be due to normal oscillations of the virus circulation, with periodic, higher magnitude outbreaks; the world bibliography reflects divergences based on the region and years analyzed..$^{5,6}$ Although possible differences related to sample collection procedures (swab tests or, nasal or nasopharyngeal aspirate specimens) and the methodology used (traditional, real-time PCR) should be considered, local data regarding children hospitalized because of an ARI were obtained based on the detection of the viral genome by traditional PCR in nasopharyngeal aspirate specimens.

A significant proportion of cases involved newborn infants and infants under 6 months old without risk factors nor associated diseases, and this suggests an early incidence of the infection which might result in hypoxemia and the need of hospitalization. Other authors reported the detection of $\mathrm{HBoV}$ in newborn infants, ${ }^{10}$ what would argue the presence of maternal antibodies with effective protection in this age group.

The rate of co-infection $(46 \%)$ is consistent with that published in all regions. ${ }^{11}$ However, for a more accurate estimate, the same approach should be used for the detection of all the microorganisms and viruses involved given that PCR sensitivity is higher than IF sensitivity.

Taking into account that winter is the season where circulating viruses are predominantly respiratory, the high co-infection rate with other viruses was initially attributed to seasonal cocirculation. However, other authors suggest that prolonged viral excretion or persistence in the respiratory mucosa, tonsils and lymph nodes could account for these findings. ${ }^{12}$ This situation, together with the identification of the virus in asymptomatic individuals initially questioned the pathogenic role of $\mathrm{HBoV}$. However, a strong correlation between the respiratory disease and the viral load ( $>10^{4} \mathrm{DNA}$ copies) has been shown, together with the detection of the virus with the highest prevalence (and in single infection) in asymptomatic subjects. ${ }^{11,12}$

Considering the causative association of $\mathrm{HBoV}$ with respiratory diseases, Meriluoto, et al., ${ }^{13}$ followed up 109 newborn infants up to their adolescence and noticed an association between the primary infection (documented by serum viral load, IgM and IgG seroconversion) and respiratory disease (high and low), which predominantly occurred in children younger than 2 years old. Conversely, in cases of re-infection no respiratory symptoms were associated.

From the clinical and epidemiological standpoint, in cases without evidence of coinfection, the diagnosis of pneumonia was predominant, with infiltrates characteristic of viral conditions in the chest X-ray and very few cases of high temperature..$^{14}$ Although they required oxygen therapy and bronchodilators, none needed mechanical ventilation nor had complications. Clinical features were similar to other respiratory viroses in this age group. ${ }^{4}$ Antibiotic use was $75 \%$, a situation frequently observed in younger infants with pneumonia. ${ }^{15}$ It is worth mentioning that results in $\mathrm{HBoV}$ detection were available to treating physicians only after discharge.

At present, $\mathrm{HBoV}$ is considered a prevalent respiratory pathogen in children younger than 2 years old and in the market there is equipment for the molecular diagnosis of a wide panel of respiratory microorganisms and viruses, among which $\mathrm{HBoV}$ is included (Film Array Respiratory Panel [RP]made by Idaho Technology Inc, xTAG Respiratory Viral Panel FAST, by Luminex, Seeplex RV15 ACE Detection, by Seegene).

This article provides information regarding $\mathrm{HBoV}$ prevalence in infants in our setting, and also the characteristics of hospitalized patients with community-acquired ARI. Even though very few conditions were described, the selection 
of clinical situations and the prospective and individualized registration of each case enable the provision of quality data.

\section{CONCLUSIONS}

HBoV prevalence in 2011 was $6.8 \%$, a rate lower than in former years, which would justify to continue with the studies about viral circulation to observe what happens during the periods with epidemic outbreaks. In positive cases without an evident co-infection, the diagnosis of pneumonia was predominant without recording severe cases nor complications at discharge.

\section{Acknowledgments}

To A. J. Roemmers Foundation and to SeCyT, Universidad Nacional de Córdoba.

\section{REFERENCES}

1. WHO. Acute Respiratory Infections (Update September 2009). [Accessed on: July 19, 2013]. Available at: http: / / www.who.int/vaccine_research/diseases/ari/en/index1.html.

2. Allander T, Tammi MT, Eriksson M, Bjerkner A, et al. Cloning of a human parvovirus by molecular screening of respiratory tract samples. Proc Natl Acad Sci USA 2005;102:12891-6. Proc Natl Acad Sci USA 2005; 102:15712. Errata.

3. Maffey A, Barrero P, Venialgo C, Fernández F, et al. Viruses and atypical bacteria associated with asthma exacerbations in hospitalized children. Pediatr Pulmonology 2010; 45:619-25.

4. Vidaurreta SM, Marcone DN, Ellis A, Ekstrom J, et al. M. Acute viral respiratory infection in children under 5 years:
Epidemiological study in two centers in Buenos Aires, Argentina. Arch Argent Pediatr 2011;109:296-304.

5. Bicer S, Giray T, Çöl D, Erda GÇ, et al. Virological and clinical characterization of respiratory infections in hospitalized children. Ital J Pediatr 2013;39-22.

6. Martin ET, Fairchok MP, Kuypers J, Magaret A, et al. Frequent and prolonged shedding of bocavirus in young children attending daycare. I Infect Dis 2010;201:1625-32.

7. Ghietto LM, Camara A, Camara J, Adamo MP. High frequency of Human Bocavirus 1 DNA in infants and adults with lower acute respiratory infection. JMed Microbiol 2012, 61:548-51.

8. Ghietto LM, Cámara A, Zhou Y, Pedranti M, et al. High prevalence of Human Bocavirus 1 in infants with lower respiratory tract disease in Cordoba, Argentina. Braz J Infect Dis 2012;16:38-44.

9. Schildgen O. Human Bocavirus: Lessons Learned to Date. Pathogens 2013; 2:1-12.

10. Villa L, Melón S, Suárez S, Alvarez-Argüelles ME, et al. Detection of human bocavirus in Asturias, Northern Spain. Eur J Clin Microbiol Infect Dis 2008;27:237-9.

11. Jartti T, Hedman K, Jartti L, Ruuskanen O, et al. Human bocavirus, the first 5 years. Rev Med Virol 2012;22: 46-64.

12. Proenca-Modena JL, Pereira Valera FC, Jacob MG, Buzatto GP, et al. High rates of detection of respiratory viruses in tonsillar tissues from children with chronic adenotonsillar disease. PLoS One 2012;7:e42136.

13. Meriluoto M, Hedman L, Tanner L, Simell V, et al. Association of human bocavirus 1 infection with respiratory disease in childhood follow-up study, Finland. Emerg Infect Dis 2012;18:264-71.

14. Moreno L, Krishnan J, Duran P, Ferrero F. Development and validation of a clinical prediction rule to distinguish bacterial from viral pneumonia in children. Pediatr Pulmonol 2006;41:331-3.

15. Collard Brosotti MV, Moreno L, Bujedo E, Marqués I, et al. Prescripción de antibióticos en lactantes hospitalizados con neumonía por virus respiratorio sincicial. Arch Argent Pediatr 2008;106:515-7. 